\title{
アルミニウム合金の $\mathrm{CO}_{2}$ レーザ溶融性に及ぼす ポリシラザン被覆の影響
}

\author{
西田典秀*，國次真輔 ${ }^{*}$ 金谷輝人**，大家利彦***，米田理史 ${ }^{* * *}$
}

\section{Effect of Polysilazane Coating on $\mathrm{CO}_{2}$ Laser Melting of Aluminum Alloys}

\author{
Norihide NISHIDA*, Shinsuke KUNITSUGU*, Teruto KANADANI**, \\ Toshihiko OOIE*** and Masafumi YONEDA***
}

Key Words : $\mathrm{CO}_{2}$ Laser, Laser Welding, Aluminum Alloys, Transparent Absorbent, Polysilazane

\section{1. 緒言}

アルミニウムは軽量, リサイクル性に優れた材料とし て，ますますその利用が期待されている材料である。一 方, アルミニウム合金のレーザ溶接は, 電子ビーム溶接 のように真空を必要としない, 高パワー密度で低入熱の 溶接が可能, 深溶け込み溶接が可能, 遠隔操作, 局部加 工, 高速溶接が可能で高能率生産を達成し得るなどの理 由から, 各種輸送用機械等における薄板の接合法として 注目され ${ }^{1)}$ ，多くの検討がされている2)。

しかし，アルミニウム合金のレーザ溶接にあたっては， 溶融部におけるポロシティなどの欠陥の発生がしやすい ことに加え, レーザ光に対する反射率が高いことが，ア ルミニウム合金のレーザ溶接の実用化を阻害する要因の 一つとされている1)。

著者らは, アルミニウムに透明膜を形成しうる無機高 分子化合物のポリシラザンを被覆することで, 被加工物 の外観を損なうことなく, 市販黒鉛塗布剤と同等の $\mathrm{CO}_{2}$ レーザ光吸収効果が得られることを既に示した ${ }^{3)}$ 。

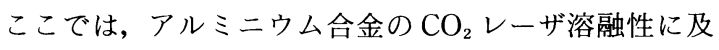
ぼすポリシラザン被覆の影響を調ベ, レーザ溶接用被覆 剤としての可能性を検討した。

\section{2. 実験方法}

基板には溶接に適した Al-Mg 系合金, JIS

* 岡山県工業技術センター（テ701-1296 岡山県岡山市芳賀 5301)

Industrial Technology Center of Okayama Pref. (5301, Haga, Okayama-shi, Okayama 701-1296)

** 岡山理科大学 (下700-0005 岡山県岡山市理大町)

Okayama Univ. of Science (Ridai-cho, Okayama-shi, Okayama 700-0005)

***四国工業技術研究所（テ761-0301 香川県高松市林町 2217 $-1)$

Shikoku National Industrial Research Institute (2217 -1, Hayashi-machi, Takamatsu-shi, Kagawa 761-0301)
A 5052 (JIS 規定成分 $(\%) \mathrm{Mg}: 2.2 \sim 2.8, \mathrm{Mn}: 0.10$ 以 下, $\mathrm{Cr}: 0.15 \sim 0.35$ ), A 5083 (同 $\mathrm{Mg}: 4.0 \sim 4.9$, $\mathrm{Mn}: 0.40 \sim 1.0, \mathrm{Cr}: 0.05 \sim 0.25)$ を選択し, 厚さ 4 $\mathrm{mm}$ の市販合金板を $50 \mathrm{~mm} \times 200 \mathrm{~mm}$ に切断し, アセ卜 ンによる超音波洗浄後実験に供した。ポリシラザン4) (東燃俐製 以下 PHPS)の被覆はディッピング法を採 用し, キシレン $-20 \mathrm{wt} \%$ ポリシラザン溶液からアルミ ニウム板を引き上げ被覆した。引き上げ後, $150^{\circ} \mathrm{C} て ゙ 30$ 分加熱処理することで溶剤を飛散させ, 厚さ $1.4 \mu \mathrm{m}$ の PHPS 皮膜を形成させた。なお, 被覆層の厚さは断面 の顕微鏡観察より求めた。レーザ照射は最大出力 $5 \mathrm{~kW}$ の $\mathrm{CO}_{2}$ レーザ(三菱電機(侏製 ML $6050 \mathrm{C}$ ) を用い, 出 力: $2 \mathrm{~kW}, 2.5 \mathrm{~kW}(\mathrm{cw})$, 送り速度: $1 \sim 4 \mathrm{~m} / \mathrm{min}$, ジャストフォーカス $(\mathrm{f}=254 \mathrm{~mm})$, シールドガス: $\mathrm{Ar}$ の条件で行った。照射後の溶融部の断面組織の顕微鏡組 織観察を行い, 溶融部の深さを測定することでレーザ加 工性の評価を行った。

\section{3. 結 果}

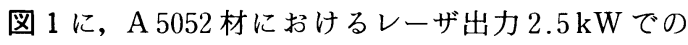
送り速度と溶け込み深さの関係を示す。PHPS 被覆材 では $4 \mathrm{~m} / \mathrm{min}$ の送り速度において $1.8 \mathrm{~mm}$ の溶け込み 深さが得られ, 送り速度の低下とともに溶け込み深さは 增加し, $1 \mathrm{~m} / \mathrm{min}$ の送り速度で $2.5 \mathrm{~mm}$ の溶け込み深さ が得られる。一方, 未処理材においては, 溶け込み深さ は被覆材に比べ格段に小さく $0.2 \mathrm{~mm}$ 程度になる。なお, 未処理材において送り速度 $2.5 \mathrm{~m} / \mathrm{min}$ 以下での照射は, 反射光によりレーザ加工機の光学系を損傷する可能性が あるため行っていない。次に, PHPS 被覆材, 未処理 材での代表的なレーザ溶融部の断面組織を図 2 に示す。 溶け込みの形態は，未処理材では熱伝導型であるが，被 覆材では深溶け込み型の溶融形態が得られている。この ように, PHPSの被覆によりレーザ溶け込み深さ, 形 態に明瞭な差が生じる。 


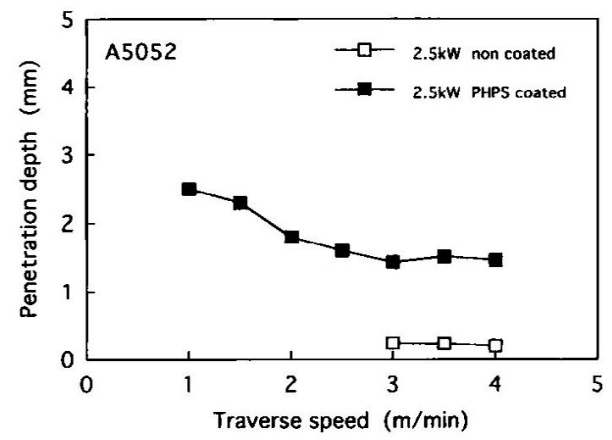

Fig. 1 Effect of PHPS coating on penetration depth of laser melted zone in A 5052 alloy at various traverse speed.
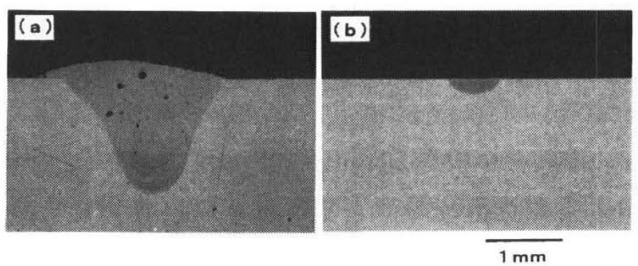

Fig. 2 Optical micrograph of cross section of the laser melted zone in PHPS coated A 5052 alloy (a) and non coated A 5052 (b) at the condition of laser power of $2.5 \mathrm{~kW}$ and the traverse speed of $3.5 \mathrm{~m} /$ $\min$.

図 $3 に \mathrm{~A} 5083$ 材での送り速度と溶け込み深さの関係 を示す。被覆材においては出力 $2 \mathrm{~kW} て ゙$ 梁溶け込みが得 られている。A 5052 材に比べより低出力で深溶け込み 型の溶融への移行が得られるのは, 合金成分の $\mathrm{Mg}$ 含 有量がA 5083 材で多いためと考えられ, 従来の報告と 一致する ${ }^{5}$ 。一方, 未処理材での深溶け込み型への移行 は, 被覆材より高出力の $2.5 \mathrm{~kW}$ のレーザ照射で生じた。 末処理材, 被覆材ともに深溶け込み型の溶融が得られる 出力 $2.5 \mathrm{~kW}$ の照射条件下においても, 板厚を貫通する 溶け込みになる $1 \mathrm{~m} / \mathrm{min}$ を除いて，すべての条件下で 被覆材の溶け込み深さが末処理材のそれを上回っている。 一般に, 金属材料のレーザに対する反射率は, 金属が溶 融すると大きく低下することが知られている。このため, 末処理材においても一旦溶融が生じると, 被覆材と同程 度の溶け込みが得られることになる。しかし，切断や溶 接などレーザ照射部が移動する加工においては，照射部 の先端に末溶融部があることになり, 高反射率の表面の

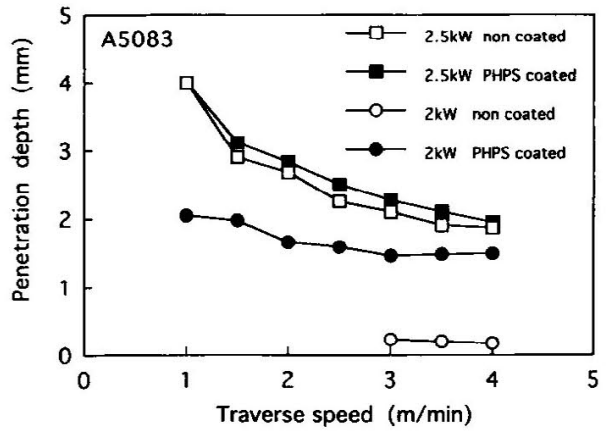

Fig. 3 Effect of PHPS coating on penetration depth of laser melted zone in A 5083 alloy at various traverse speed.

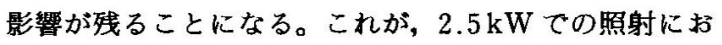
ける，被覆材と末処理材の差になったものと考えられる。 このように, PHPS 被覆により同一の溶け込み深さを 得るためのレーザ出力の低下が期待でき，入熱過唾によ る溶け落ちなどの欠陥 ${ }^{6)}$ を隇少させうる可能性を示唆し ている。

\section{4. 結論}

アルミニウム合金 A 5052, A 5083 の $\mathrm{CO}_{2}$ レーザ溶融 性に及ほすすにポリシラザン被覆の影響を検討した。その 結果 $1.4 \mu \mathrm{m}$ 厚さのPHPS 被覆により未処理材に比べ, 熱伝導型から深溶け込み型の溶融への移行がより低出力 下で生じることが確認され，PHPS 被覆が $\mathrm{CO}_{2}$ レーザ 溶接におけるレーザ吸収率向上に有効であることが示さ れた。

(Received May 31, 1999 : Accepted August 25, 1999)

\section{文献}

1）軽金属溶接構造協会レーザ溶接委員会；軽金属溶接，30，297 (1992)

2）例えば片山誠二, Carl D. Lundin；軽金属溶接，29，295 (1991)

3）西田典秀, 國次真輔, 野上輝夫, 金谷稫人, 大家利彦, 米田理 史：溶接協会第 23 回表面改質委員会资料 (1997)

4）東燃ポリシラザン資料；東败体セラミック事業室（1997）

5) 片山誠二, 松縄 朗; 第 43 回レーザ熱加工研究会論文集, p. 33 (1998)

6）松本 剛, 吉田正敏; 第 43 回レーザ熱加工研究会論文集, p. 72 (1998) 